\title{
アデノウイルスの研究
}

（補体結合性抗原の検討孝中心子して）

\author{
武田宏

\section{STUDIES ON ADENOVIRUS WITH SPECIAL REGARD TO COMPLEMENT FIXING ANTIGEN}

\author{
Hiroshi TAKEDA*
}

〔受稿 7 月 3 日，1961]

アデノウイルス活現在人間拉よび猿から 24 以上の血 清学的に異る型分分離されており，臨床的には胭頭結膜 熱, 流行性角結膜炎, 異型肺炎气の他感胃様疾患の原因 として知られている。一方本ウイルスに関寸る基礎的研 究も数多くなされている (Pereira, 1959 a).

アデノウイルス群は主として中和試験によつて各型に 分所られるが，その補体結合抗原（以下 CF 抗原）は各 型に共通でアデノウイルス群に特異的であつて，しかも ウイルス粒子と証異るいわゆる可溶性 (soluble) 抗原 (以 下 S 抗原)であるとされている，ウイルス粒子自体の CF

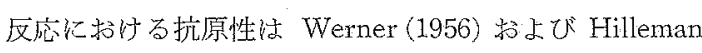
ら(1955)によつてわずかに暗示されてはいるもののその 詳細について致在全く不明といわざるをえない。

この論文においてはウイルス粒子の CF 抗原（いわゆ るV抗原) の存在を明らかにし、V抗原と S 抗原の性質 を比較すると同時に，V抗原招よびS 抗原の異同を解明 するために試みられた二三の実験が報告される。また予 備実験として行われた感染価測定法の条件の検討と，え られた新条件による增殖曲線と CF 抗原および細胞変性 効果 (Cytopathogenic effect, C:P.E.) 出現との時間的関 係につマても報告され，先人の業績と比較検討される。

\section{材 料と方法}

\section{1. 実験材料}

ウイルス：アデノウイルスの標準株 3 型 (G-B 株), I 型 (adenoid 71) を使用した.これらのウイルス（伝

\footnotetext{
* 零応羲熟大学院医学研究科（指導: 三方一沢教授）
} (指導: 牛場大藏教授)

Doctor's Course, Dep. of Int. Med., School of Med., Keio Unniversity.

Director: Prof. I. Mikata, Prof. D. Ushiba
研より分与を受けた）はわれわれの研究室で HeLa 細胞 を用いて継代しているもので，感染細胞を培養液と共に 凍結融解 6 回後, 4,000 rpm 30 分の遠心 沈激上清をウ イルス液として使用した.

細胞および組織培養液：HeLa 細胞を用いた。增殖 用培養液としては lactalbumin hydrolysate $0.5 \%$ 加 Hanks 液何血清を $20 \%$ ，二ワトリ胎児浸出液 (1: 1) を゙ $2 \%$ に含ませ，更に streptomycin $100 \mathrm{mcg} / \mathrm{ml}$, penicillin 100 単位 $/ \mathrm{ml}$ 妾加えた液を用、底. 維持用培養液 としては lactalbumin hydrolysate $0.5 \%$ 加 Hanks 液に 馬血清 $5 \%$, yeast extract $0.1 \%$, streptomycin 100 $\mathrm{mcg} / \mathrm{ml}$, penicillin 100 単位 $/ \mathrm{ml}$ を加えたものを用いた。 また組織培養に使用したガラス器具はすべて良質のもの で，その清浄法は Enders 研究室の方法にしたがつた (甲野. 1954).

\section{2. 実験方法}

a）感染価の測定：角嚗中に一層に発育した HeLa 細胞に 200 H.U.M./ml の trypsin 溶液 (持田製薬の trypsilin を使用) を加えて細胞をガラス面より剝し， Hanks 液にて洗い，中型試験管に約 200,000 細胞 $/ \mathrm{ml}$ の濃度の液を $0.5 \mathrm{ml}$ 大れて $37^{\circ} \mathrm{C}$ に静置培養した. 2 3日目に堌殖用培養液を捨て, 維持用培養液 $0.9 \mathrm{ml}$, ウイルス液の 3.2 倍又は 10 倍階段稀釈したもの $0.1 \mathrm{ml}$ を加えて $37^{\circ} \mathrm{C}$ に静置培養し，7日目毎に試験管内の液 を新しい維持用培養液を交換した．主として 28 日目の C.P.E. をもつて終末点を判定し, Behrens-Kärber の方 法（伝研・実習提要，1958）によって TCD 50/ml を求 めた。

b) 補体結合抗原価の測定：術式は Kolmer 変法（伝 研・実習提要，1958）を用いた。すなわち 3 単位の溶血 
素，2正単位の補体， 2 単位の抗体意使用し，抗原稀釈 法により抗原価を測定した，抗体としてはアデノウイル 又に比較的高いCF 抗体価堂有する成人男子の血清を用

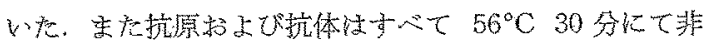

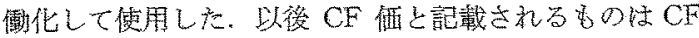
抗原価定示寸。

c）超遠心による分劃の実験：Spinco Model L, Roter No. 40 を用いた。

d) $\mathrm{CF}$ 抗原の熱抵抗性：陚料老 $1 \% \mathrm{HCl}, 1 \% \mathrm{NaOH}$ にて $\mathrm{pH} 6.1$ 亿補正し，その一定量定小試験管に分注し て $68^{\circ} \mathrm{C} \sim 75^{\circ} \mathrm{C}$ の間で1分 40 分の間温水中に入れた 後，それぞれの試料の $\mathrm{CF}$ 值を測定した。

e) ゲル内沈降反応：Ouchterlony の方法（伝研・実 習提要，1958，鈴木，1960) により Difco 寒天1\%にマ ーゾニンを0.01\%の割に加光 $\mathrm{pH}$ を 7.8 亿補正したも

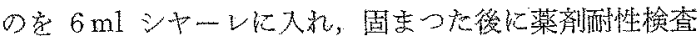
用のカップを寒天の上に招き。さらに $15 \mathrm{ml}$ の同寒天を 注いで固客つた後にこれ童取り去り，できた穴の中に㧤

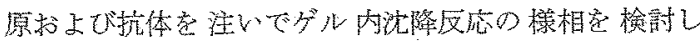
た。早小時飞注 24 時間後に沈降帯が現われたが，判定 は寒天の乾䑁を防ぐ目的でビニール製の袋に入れて 日間 $37^{\circ} \mathrm{C}$ に圆いた後に行なった。

f) エーテル処置の実験： 試料に $1 / 2$ 容のエーテル(特

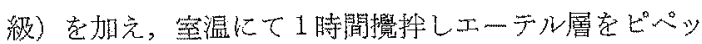
トで捨て,さらに 12 時開 $37^{\circ} \mathrm{C}$ にて保存し, 残りの土 一テルを除いて CF 価の測定を行った。

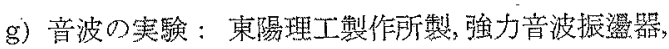
50-5型(出力10キロサイタル)を用々，音波にて1時閒 処理した陚料の CE 価沾よび感染価の測定を行なつた。

\section{成績}

1. 感染価測定法の検副。予備実験としてアデノウイ ルス 3 型感染価測定に格ける判定日数の検討を行つた.

すなわら観察期間の超最による見加讨上感染価の推移を 知るために 10 倍階段稀釈したウイルス液を各稀积 2 本 以上の細胞シー下試験管记接種し, 日定息つて, C.P.E.

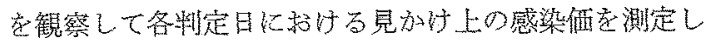
店。表1に示すごとくに7日目には $10^{1.5} \sim 10^{2.5} \mathrm{TCD}_{50}$ ! $\mathrm{ml}$ のすの゙゙ 14 日，21日と日を追つて感染価功上昇し， 7 日目之28日目で $10^{3.0} \sim 10^{3.75}$ の差意認为る。し办し 28 日以上 $\mathrm{HeLa}$ 細胞を維持することはなか子小国難で あるのでわれわれ注一応28日目で観察を打ち切つたが， 28日目で C.P.E. (一) を示した最低稀釈の試験管の細胞

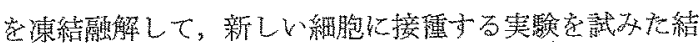
果,行なつた籍囲内では継代後28日目に特いても C.P.E.

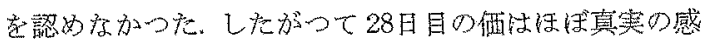

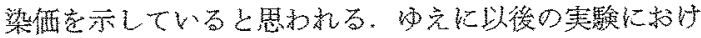
る感梁俩の測定には主として28日目に判定を行うこと ¿し庆.

Table 1. Comparison of Infectivity Titers Read after Various Periods of Incubation of Culture Tubes for Infectivity Titration of Type 3 Adenovirus.

\begin{tabular}{c|c|c|c|c|c}
\hline \multirow{2}{*}{$\begin{array}{c}\text { Experi- } \\
\text { ments }\end{array}$} & $\begin{array}{c}\text { Virus } \\
\text { prepa- } \\
\text { ration }\end{array}$ & \multicolumn{3}{|c|}{$\begin{array}{c}\text { Infectivity titers (TCD } \\
\text { determined after incubation for }\end{array}$} \\
\cline { 3 - 6 } & 7 & 14 & 21 & 28 (days) \\
2 & $\mathrm{~A}$ & $10^{2.5}$ & $10^{4.0}$ & $10^{4.5}$ & $10^{5.5}$ \\
3 & $\mathrm{~A}$ & $10^{2.5}$ & $10^{3.5}$ & $10^{5.5}$ & $10^{6.0}$ \\
4 & $\mathrm{~A}$ & $10^{2.5}$ & $10^{2.5}$ & $10^{5.0}$ & $10^{6.0}$ \\
5 & $\mathrm{~A}$ & $10^{2.5}$ & $10^{2.5}$ & $10^{6.0}$ & $10^{6.0}$ \\
6 & $\mathrm{~B}$ & $10^{2.5}$ & $10^{4.0}$ & $10^{5.5}$ & $10^{5.5}$ \\
& $\mathrm{C}$ & $10^{2.5}$ & $10^{4.0}$ & $10^{5.0}$ & $10^{5.25}$
\end{tabular}

2.アアデノタイルス 3 型にむける感染性马イ夗ス粒子 $\varepsilon \mathrm{CF}$ 抗原出現の時間的関係

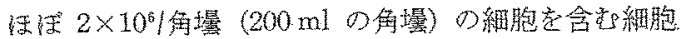
シート(角壊)多数に $10^{7} \mathrm{TCD}_{50} /$ 角嚗のアデノウイルス 3 型ウイルス液を接種し，3時間 $37^{\circ} \mathrm{C}$ にて吸着させた 後, Hanks 液にて 3 回洗い, 以後時間を追つて(接種時 を０時間とした）角壜を取りだして C.P.E，を観察した

Fig. 1 The growth characteristics of type 3 adenovirus.
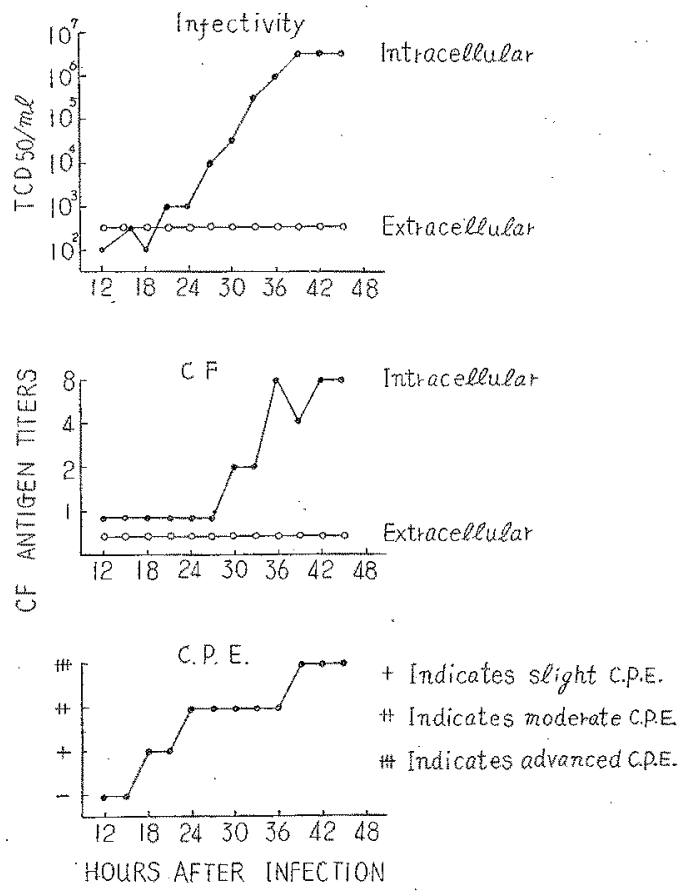
後，直ちに涷結保存し，ま之めて同時に感染洒衫よび CF 価の測定を行なつた。感染価に関しては細胞で蛙 21 時閒より上异し始为たが培地の中では 46 時間に执いて

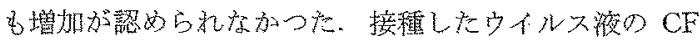
価性 32 で㟧つたが，細胞に感染後 27 時間まで梳 CF 抗 原莸検出できず，細胞で驻 30 時間で 2 そなり，36 時間

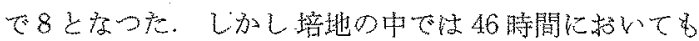
CF 抗原を検出できなかつた. C.P.E. は細胞の比較的少 、所を見ると 18 時間より認的られるよらとなり24時閒 で+となった，感染価敌よび CF 価の時間的関係を見る とウイルス粒子の感染価よりやや就くれて CF 抗原が検 出さ礼るようになる。

\section{3. ウイルス粒子のCF 度応}

a) アデノウイルス 3 型ウイルス液を 40,000 rpm 60

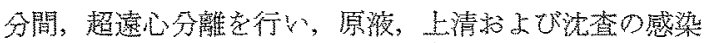
価と CF 洒在測定すると表 2 のごとくで $40,000 \mathrm{rpm} 60$ 分でウイルス粒子の示主感染洒㹥沈渣に集ることが分つ たが，この場合の沈渣の CF 価は 3.2 となる。一方その 時の上清の価は 4 で原液比比してすずか低いに過ぎない ので，沈渣恃 40,000 rpm 60 分でいわゆる可溶性 S抗原 の一部が落らることを示すのではないかと云うことが疑 われた，そこでさらに次の実験を行なつた。

Table 2. Complement Fixing Antigen and Infectivity Titers of Fractions Obtained by Ultracentrifugation from Type 3 Adenovirus Preparation.

\begin{tabular}{l|c|c}
\hline Fractions tested & $\begin{array}{c}\text { CF antigen } \\
\text { titers }\end{array}$ & $\begin{array}{c}\text { Infectivity titers* } \\
\text { (TCD }\end{array}$ (m) \\
\hline $\begin{array}{l}\text { Original (non-treated) } \\
\text { Supernatant from } \\
40,000 \mathrm{rpm}, 30 \mathrm{~min} .\end{array}$ & 8 & $10^{3.5}$ \\
$\begin{array}{l}\text { Sediment from } \\
40,000 \mathrm{rpm}, 30 \mathrm{~min} .\end{array}$ & $3.2^{* *}$ & $10^{1.5}$ \\
$* \begin{array}{l}\text { In this Experiment, the titer was determined } \\
\text { after } 1 \text { week incubation. }\end{array}$ \\
** Calculated from CF antigen titer of 10 fold \\
concentrated sample.
\end{tabular}

b) $40 \mathrm{ml}$ のアデノウイルス 3 型拉よび 1 型ウイルス 液堂 $8 \mathrm{ml}$ づつ 5 本の遠沈管に分济 $15,000 \mathrm{rpm} 30$ 分で 沈溊する粒子 (“15,000 沈渣”) 炭先ず落し，その上清 (“15,000 上清”) $27 \mathrm{ml}$ を $9 \mathrm{ml}$ づつ 3 本の遠沈管に

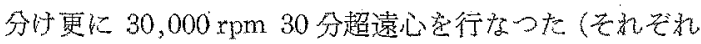
“30,000 上清, 沈渣”). 更に “30,000 上清”の $20 \mathrm{ml}$ を 40,000 rpm 60 分超遠心を行なつて沈敗する粒子を 落した（そ档ぞれ“40,000 上清，沈督”）。上記のご とくにしてえられた“15,000，30,000４40,000，沈渣”
をそれぞれ $8 \mathrm{ml}$ の Hanks 液に浮游させて 40,000 rpm 60 分超遠心にて洗絡し，沈渣を乞れぞれ出発の $1 / 10$ 量の Hanks 液に浮游させて 10 倍濃縮の沈渣浮游液孛作製し た.このよらにしてえられた上清，沈渣の CF 伍を測定 した，結果は表3のごとくで1型，3型共に同様の態度

Table 3. Complement Fixing Antigen Titers of Several Fractions Obtained by Ultracentrifugation from Type 3 and 1 Adenovirus Preparatons.

\begin{tabular}{|c|c|c|}
\hline \multirow{2}{*}{ Fractions tested } & \multicolumn{2}{|c|}{$C F$ antigen titers } \\
\hline & Type 3 & Type 1 \\
\hline Original (non-treated) & 16 & 32 \\
\hline $\begin{array}{l}\text { Supernatant }(15,000 \mathrm{rpm}, \\
\quad 30 \mathrm{~min} .) \cdots \cdots \cdots \cdots\end{array}$ & 16 & 16 \\
\hline Sediment $(15,000 \mathrm{r} \mathrm{pm}, 30 \mathrm{~min} .)^{*}$ & $0.8 * *$ & $1.6^{* *}$ \\
\hline $\begin{array}{l}\text { Supernatant }(30,000 \mathrm{rpm}, 30 \mathrm{~min} .) \\
\quad \text { from }(\mathrm{A}) \ldots \ldots \ldots \ldots(\mathrm{B})\end{array}$ & 16 & 16 \\
\hline $\begin{array}{l}\text { Sediment }(30,000 \mathrm{rpm}, 30 \mathrm{~min} .) \\
\quad \text { from }(\mathrm{A})^{*}\end{array}$ & $0.1 * *$ & $0.4^{* *}$ \\
\hline $\begin{array}{l}\text { Supernatant }(40,000 \mathrm{rpm}, 60 \mathrm{~min} .) \\
\text { from }(B)\end{array}$ & 8 & 16 \\
\hline $\begin{array}{l}\text { Sediment }(40,000 \mathrm{rpm}, 60 \mathrm{~min} .) \\
\text { from }(\mathrm{B})\end{array}$ & $0.2^{* *}$ & $0.8^{* *}$ \\
\hline
\end{tabular}

* Each sediment was washed once more with

- Hank's balanced solution of $40,000 \mathrm{rpm}$ for 60 minutes.

** Calculated from CF antigen titer of 10 fold concentrated sample.

をとり、“15,000,30,000,40,000 沈渣”のいずれ もわずかではあるが $\mathrm{CF}$ 反応を起寸ものがあること就よ びその半分以上は $15,000 \mathrm{rpm}$ に乱いて落ちることを示 している.この場合浓渣へのはじめのS 抗原の污染は,

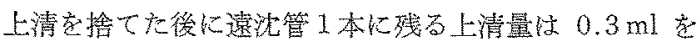
越えることはない(科量により測定された)ことから計算 すると、“15,000 沈渣”は 5 本の遠沈管の沈澘集奻 て Hanks 液 $8 \mathrm{ml}$ に浮游し, さらに 40,000 rpm 60 分 超辜心して沈渣を $4 \mathrm{ml}$ に浮游させたのであるから $\frac{8}{0.3 \times 5} \times \frac{4}{0.3}=70$ となりまた“30,000 沈渣” “40.000 沈渣”吕それぞれ約 90 となるので，沈渣に

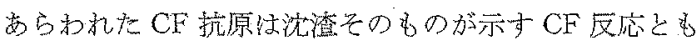
考它られるとはいらものの，な极はじめ上清中汇含要 和るS抗原の污染炕よつても同樣の結果多えられる可能 性もるるので，污染比よる反応を全く除外する目的で，

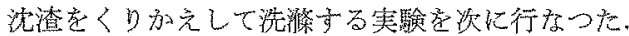

c) $18 \mathrm{ml}$ のイルス液を 2 本の遠心管に分け，40,000 rpm 60 分超遠心少行なつ上清の一部老静か儿取つて “上清”とし，沈渣を $18 \mathrm{ml}$ の Hanks 液に浮游させ 
Table 4. Washing Experiments of Sediments of Type 3 Adenovirus Preparation by Centrifugation at $40,000 \mathrm{rpm}$ for 60 Minutes.

\begin{tabular}{l|c|c|c}
\multicolumn{1}{c|}{ Fractions tested } & $\begin{array}{c}\text { Infectivity } \\
\text { titers } \\
\left(\mathrm{TCD}_{50} / \mathrm{ml}\right)\end{array}$ & $\begin{array}{c}\text { CF antigen } \\
\text { titers }\end{array}$ & $\begin{array}{c}\text { Supposed dilution of } \\
\text { S antigen contaminated } \\
\text { from Original fraction }\end{array}$ \\
\hline Original (non-treated) & $10^{6.75}$ & 64 & $1: 1$ \\
Supernatant from 1 st. centrifugation & $>10^{3.75}$ & 32 & $1: 1$ \\
Sediment from 1st. centrifugation & $10^{6.75}$ & 4 & $1: 30$ \\
Fluids from 1 st. washing of sediment & $>10^{3.25}$ & 1 & $1: 30$ \\
Sediment washed once & $10^{6.0}$ & 2 & $1: 700$ \\
Fluids from 2 nd. washing of sediment & $>10^{3.25}$ & $<1$ & $1: 700$ \\
Sediment washed twice & $10^{5.5}$ & 1 & $1: 20,000$
\end{tabular}

Table 5. Washing Experiments of Sediments of Type 3 Adenovirus Preparation by Centrifugation at $15,000 \mathrm{rpm}$ for 30 Minutes.

\begin{tabular}{l|c|c|c}
\hline \multicolumn{1}{c|}{ Fractions tested } & $\begin{array}{c}\text { Infectivity } \\
\text { titers } \\
\left(\mathrm{TCD}_{50} / \mathrm{ml}\right)\end{array}$ & $\begin{array}{c}\text { CF antigen } \\
\text { titers }\end{array}$ & $\begin{array}{c}\text { Supposed dilution of } \\
\text { S antigen contaminated } \\
\text { from Qriginal fruction }\end{array}$ \\
\hline Original (non-treated) & $10^{6.5}$ & 64 & $1: 1$ \\
Supernatant from 1 st. centrifugation & $10^{4.5}$ & 64 & $1: 1$ \\
Sediment from 1 st. centrifugation & $10^{6.25}$ & 4 & $1: 30$ \\
Fluids from 1 st. washing of sediment & $10^{4.5}$ & 2 & $1: 30$ \\
Sediment washed once & $10^{5.75}$ & 2 & $1: 700$ \\
Fluids from 2 nd. washing of sediment & $10^{4.75}$ & $<1$ & $1: 700$ \\
Sediment washed twice & $10^{5.75}$ & 1 & $1: 20,000$
\end{tabular}

Table 6. Thermal Differentiation of Complement Fixing Antigen Titers between Supernatant and Sediment of Type 3 Adenovirus Preparation by Centrifugation at $15,000 \mathrm{rpm}$ for $30 \mathrm{~min}$. (pH 6.1)

\begin{tabular}{|c|c|c|c|c|c|c|c|c|c|c|c|c|}
\hline \multirow{3}{*}{ Fractions tested } & \multirow{3}{*}{$\begin{array}{l}\text { Non- } \\
\text { heated }\end{array}$} & \multicolumn{11}{|c|}{ Relative CE antigen titers* } \\
\hline & & \multicolumn{3}{|c|}{$68^{\circ} \mathrm{C}$} & \multicolumn{3}{|c|}{$70^{\circ} \mathrm{C}$} & \multicolumn{3}{|c|}{$73^{\circ} \mathrm{C}$} & \multicolumn{2}{|c|}{$75^{\circ} \mathrm{C}$} \\
\hline & & 20 & 30 & 40 & 5 & 10 & 15 & 2 & 4 & 6 & 1 & $2 \mathrm{~min}$. \\
\hline Supernatant & 1 & 1 & $1 / 2$ & $1 / 2$ & 1 & $1 / 2$ & $1 / 2$ & $1 / 2$ & $1 / 4$ & $1 / 8$ & 1 & $1 / 4$ \\
\hline Sediment** & 1 & $1 / 2$ & $1 / 2$ & $1 / 2$ & $1 / 2$ & $1 / 2$ & $1 / 2$ & $1 / 2$ & $1 / 4$ & $1 / 4$ & $1 / 2$ & $1 / 4$ \\
\hline
\end{tabular}

* These values indicate relative CF titer when CF titer of nonheated sample is expressed to be 1 .

** Sediment washed twice.

て“沈渣”とした.この場合上清の污染は遠沈管 1 本 k $0.3 \mathrm{ml}$ 残ると仮定すると約 ${ }^{1 / 30}$ となる. 次に $14 \mathrm{ml}$ の“沈渣”の浮游液を 40,000 rpm 60 分遠沈古行い, 再び沈椬を $14 \mathrm{ml}$ の Hanks 液に浮游させて“1回洗涤 沈渣”とし，その一部をとつてさらにもう一度洗滌を 繰り返して“2 回洗滌沈渣”をえた。はしめの“上 清”の污染は 1 回および2 回の洗滌でそれぞれ約 $1 / 700$, 1/20,000となる.以上のごとくにして得られた試料につい てそれぞれの感染価执よび CF 価を測定した。結果は表 4 に示ずごとくで，感染価（ウイルス粒子）の大部分が 1 回の遠沈で沈渣に集つた. この時 CF 価汢原液 64, 上
清 32 ，沈渣 4 であつたこの沈椬に詨する“上清””の 污染汇約 $1 / 30$ と教えられるので, 沈渣の CF 価 4 は上清 (S抗原) の污染による CF 反応を否定することはできな い.しかし1回洗滌により沈渣の CF 洒 4 であつたもの が 2 となり，約半分に低下したが，この時の感染価の減 少任 $10^{6.75}$ 加 $10^{6.0}$ となつて感染価も同時に減少してい るので遠沈操作による損失と考えられ，しが “上清” のうすまり方は約 $1 / 700$ である.したがつてこの CF 価は 上清の励染では説明がつか子ず，洗滌沈渣にもCF 抗原性 があることを明らかに示している。さらに繰り返した洗 浟に执いてほぼ同様の結果である。すなわち CF 抗原が 
沈渣に現れて，遠沈の繰り返しによるその減り方は感染 価の減り方とほぼ平行しているといら結果がえられた。

d）そこで同様の方法で $15,000 \mathrm{rpm} 30$ 分でウイル 不粒子を洗うと,成績は表 5 のごとくになり，40,000 $\mathrm{rpm}$ の場合とほとんど同じ結果がえられた。

4. 沈渣の補体結合性物質（以下一応これを“V 抗 原”とよぶ）といわゆる、抗原との比較.

a）熱抵抗抗： $S$ 抗原と “ $V$ 抗原” との熱抵抗性を 比較すると成續は表 6 のごとくで，CF 価の熱による減 少率は $\mathrm{S}$ 抗原と“V抗原”との間で差が認められなか つた.

b) エーテル 処理：“15,000 rpm 30 分 2 回洗滌沈 渣”をエーテル処理を行なつたが処理前後の CF 価は いず机も2で“V抗原”はエーテル処理を行なつても CF 洒に変動はなかつた。

c）音波による実験：“15,000 rpm 30 分 2 回洗滌沈 渣”を 1 時間音波にかけその感染価，CF 価を測定し た．結果は表 7 と示すごとくで， $\mathrm{TCD}_{50} / \mathrm{ml}$ に関しては $10^{8.0}$ のものが $10^{5.5}$ となり感染価を有するウイルス粒 子注約 $1 / 300$ に減じた。一方 CF 洒恃音波処理後のものは 音波処理前に較べて 2 倍上昇していた. CF 反応は 2 回
Table 7. Influences 'of Sonic Oscillation on Complement Fixing Antigen and Infectivity Titers of Twice Washed Sediments of Type 3 Adenovirus.

\begin{tabular}{c|c|c}
\hline Sample & $\begin{array}{c}\text { CF antigen } \\
\text { titers }\end{array}$ & $\begin{array}{c}\text { Infectivity titers } \\
\text { (TCD } 50 / \mathrm{ml})\end{array}$ \\
\hline $\begin{array}{c}\text { Non-treated } \\
\begin{array}{c}\text { Sonicated for } \\
1 \text { hour }\end{array}\end{array}$ & 4 & $10^{8.0}$ \\
\hline The & 8 & $10^{5.5}$
\end{tabular}

行なつたがいずれも同じ結果をえた。

d）ゲル内沈降反応：Ouchterlony の方法によりゲル 内沈降反応を行つた。 すなわち図 2 a に示すごとく抗 血清 (S) とウイルス原液 (A), 15,000 rpm 30 分上清 (B)，および 2 回洗滌沈渣 (C) との間にそれぞれやや太 い1本の沈降帯を認め，これらはその端において合致し 連絡している。また $S$-B間に現れた沈降帯に較べて抗原側に接近していた.

次に音波処理の試料を用いてゲル内沈降反応を行なつ

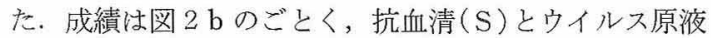
(A)および超遠心上清 $(\mathrm{B})$ との間汇はそれぞれ 3 本の細 々沈降带が現れた(一応 $\alpha, \beta, \gamma$ とする).この場合使用

Fig. 2 Comparison of Supernatant-and sedimentfractions obtained by ultracentrifugation from type 3 adenovirus preparation by the aid of gel-diffusion technic.

(a)

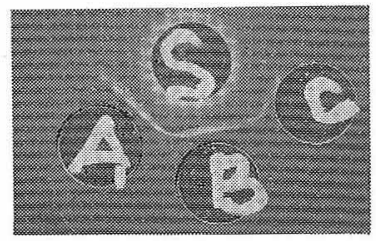

(b)

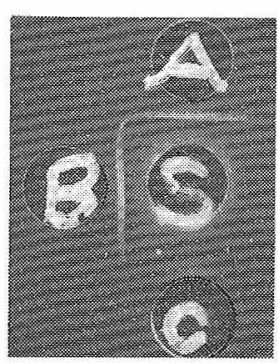

(c)

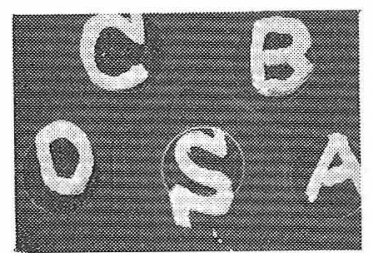

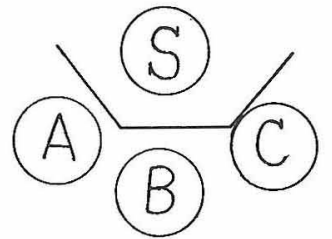
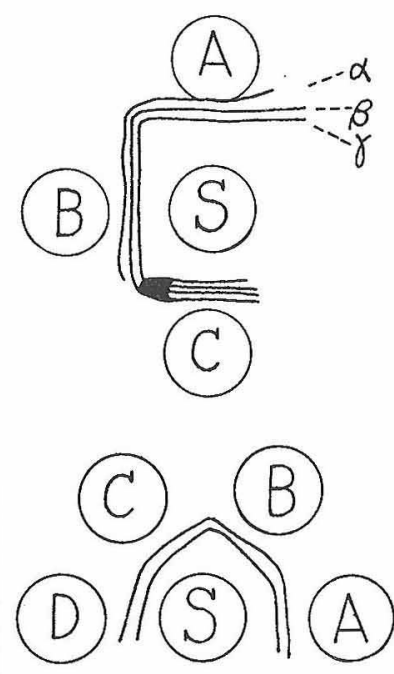

S.: Antiserum

A : Original virus preparation

B : Supernatant from 15,000 r.p.m., 30 min.

C: Sediment washed twice by 15,000 r.p.m., $30 \mathrm{~min}$.

S: Antiserum

A : Original virus prearation

B : Supernat from 15,000 r.p.m., $30 \mathrm{~min}$.

C: Sediment washed twice by 15,000 r.p.m., $30 \mathrm{~min}$. and Soni-Cated for 1 hour

S: Antiserum

A : Sediment waseed by 15,000 r.p.m., 30 $\min$.

B : Supernatant from 15,000 r.p.m., 30 min. and sonicated for 1 hour

C: Supernatant from 15,000 r.p.m., 30 min.

D : B 
した試料は図 2 a の場合に用いた試料と全く同一であり 条件もまた全く同一としたにもかかわらず実験により 3

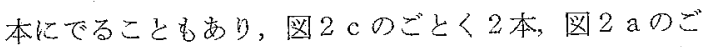
とく1本にでることも㐫つたが，これは微妙な条件の差 によるものであるら。それはをむかく，図2 bに括忛る 音波処理後の $(\mathrm{C})$ に愊の広い沈降带があらわれ，その 中にはあまり明膫ではない 4 5 本の細い沈降带が観察 され，全体をして端に掠いて S-B 間の $\beta, \gamma$ と連絡し ている像がえられた。

対照として“上清”（S抗原）に音波を1時間かけゲ ル内沈降反忘を行つたが音波処理前後で全く差学認めな 加店。(図 $2 \mathrm{c}$ )

\section{考察}

アデノウイルスの堌殖に関する研究はすでにいくつか の研究が報告されている(Fukumi ら, 1957, Ginsberg, 1958; Lieberman ら, 1959, Pereira ら, 1959 b, 甲野 ら. 1960)。またウイルス增殖と CF 抗原出現の時間的 関係もこれらの研究者によつてとり㐫げられているが， ウイルス粒子と CF 抗原生成上の関係を知る上で興味が ある、私の実験では感染価の上昇の始まる時間は 21 時 間であつたが, Lieberman ら(1959)の 1，4，5，6 型に ついての実験では 16 22 時閐であり，甲野ら(1960)の 3 型の実験では低濃度のウイルスを接種した時が 36 時 間，高源度の場合は 12 時間であった。また CF 価に関 しては私の実験によると，細胞では 30 時閏より CF 価 が上昇し始めたが，液層では 46 時間でもその上昇を認 めなかつた。この種の実験では Lieberman ら (1959) も 指摘しているように細胞の状態とかウイルスの吸着の割 合などに多分の影響を受けるので，多少の時間の差はや むをえないすのであるう。いづれにせよ CF 価の上昇が 感染価の上昇上り痋れている点では共通して括り，私の 実験でもそうであつた。この点より CF 抗原はウイルス 粒子の前駆物質 (Precursor) でなく副産物 (by-product) であるとする Lieberman の説は一見正しいようにも思 わ秃るが，補体結合反忘は微量の抗原の検出には適当で ないので $\mathrm{CF}$ 価の時間的推移のみで $\mathrm{CF}$ 抗原がウイル ス粒子の前駆物質でないとすることは無理であるう。

C.P.E. は 18 時閪より始まつているが，これは Rowe ら (1958)，抒よび Pereira (1958)の云う毒素作用によるも のと思われる。

アデノウイルスのウイルス粒子を CF 抗原を超䞦心で 分けうることは Rowe ら (1955) および Hilleman ら (1955)により明らかである。すなわち Rowe は 10,000 $\mathrm{rpm} 3$ 時間 2 回, Hilleman は SW 39 roter で 24,630 rpm 30 45 分でウイルス粒子と CF 抗原を分けている.
私もこれを追試したがその途上ウイルス粒子の洗滌を繰 り返してもかずかではめるがウイルス粒子の分劃に CF 反店性が残ることを認めた. Werner (1956) は 3 型ウイ ルス液を超遠心分離を行い，その沈渣(ウイルス抗原）で モルモットを免疫したところ，その血清は CF 反応で型 特異的でなく，3 型， 7 型小ずれの可溶性抗原とも CF 反応を起すことを観察しウイルス粒子は群特異的の抗原 を含んでいて，この群特異的抗原はウイルス粒子の表面 にあるのであるらと述べている. Hilleman ら (1955) も 超遠心で分村たウイルス粒子が僅か子がら CF 区応を起 寸所から CF 抗原の一部は顆粒状になつているか, ある いはウイルス粒子の表面に附着しているのかも知れない と云うことを述へている。これらの報告と上述の実験成 績はよく一致しているので，さらにこの“V抗原”に ついて研究を進めた。

超遠心沈渣に補体結合性が表れる場合の可能性につい て㹲えてみると

（1）可溶性抗原とは異つた抗原性物質がウイルス粒子 にあって，それがS抗体とは別のいが可抗体と反 応卞る場合。

（2）可溶性抗原と同じものが反応に関与している場合 としては

a) ウイルス粓子自体の構成成分としてS抗原が存 在する場合

b）ウイルス粒子の表面に吸着された形で $\mathrm{S}$ 抗原が 存在する場合

c) S抗原の一部は $15,000 \mathrm{rpm}$ であ沈溊する大き さの粒子として，ウイルス粒子とは別に存在する 場合

などがある，前述の可能性を証明するには可溶性抗原， および“V抗原”に対するそれぞれの抗血清がえられ なけ尗ばならないが末だ成功していない，しかしこれ とは全く別の方法で私が行つたゲル内沈降反応の結果を

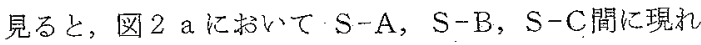
た沈降帯はそれぞれ連絡している所から“洗洋沈渣” に含まれる抗原性物質はウイルス原倠掠よび S抗原に含 まれる抗原性物質とその特異性に捻いて同一であること を意味している，したがつて (1)の可能性注除外出来， （2）の可能性の a，b，cいずれかであらうと考えられる. また図 2 aのS-C間の沈降带が, S-A，S-B間に現れ た沈降帯に較べて抗原側に接近していることは“洗㴪 沈渣”中に含まれる抗原性物質の量名 A，Bに含まれ る抗原性物質より少いこと，あるいは抗原性物質の寒天 内拡散速度の抢そいことを意味している。また図 2 bの $\mathrm{S}-\mathrm{A}, \mathrm{S}-\mathrm{B}$ 間の抗原側の $\alpha$ は Pereira の early cyto- 
pathic factor に，他の2本 $(\beta, \gamma)$ は CF 抗原 ( S 抗原) に相当すると思われる，前述の可能性（2）について考え てみると，超遠心の成績において沈渣の CF 価の減り方 と感染価の減り方がほぼ平行していた專実は沈渣におけ るCF反応性がウイルス粒子そのものと何等加の関係を 有していること腤示するものであるう。したがつて可 能性 (2) a ⿷たは (2) b が最も考光易いが。一方 (2) c の 可能性を完全に否定することはできないであるら。

Friedman ら (1959) はアデノウイルスの 1，2，5，6型 と $3 ， 4 ， 7 ， 8$ 型で CF 抗原の熱抵抗性に差加岁ると を述べているが，S抗原と“V抗原”との比較をする ために熱抵抗性試験莸試多たところ，熱に対する抵抗性 に注差が認められなかつた。をだ、抗原”のエーテ ル処理党試多たが CE 洒の上昇を認めなかつた。エーテ ル処理に関してはインフルエンザウイルス，リフトバレ 一熱ウイルスについてそれぞれ Lief and Henle(1956), 野島ら (1957)の報诺が市り，これらのウイルスに执いて 壮エテルによりウイルス構成成分のV抗原が遊離して きて，CF 洒の上昇をきたしたと考えられているが，ア デノウイルスはエーテル耐性のためか差を認めなかつ 记。

“V抗原” に音波老 1 時間加けると $\mathrm{TCD}_{50} / \mathrm{ml}$ は $10^{8.0}$ 方 $10^{5.5}$ に減少しその差は約 $1 / 300$ である。一方 CF 価注 2 偣上昇している。このことはウイルス粒子少破壊 されたため構成成分が遊離して CF 洒が上萃したことを 意味していると考えるのが最も妥当であるら（可能性 (2) a).しかしS抗原の一部がウイルス粒子の表面に強固に 附着している場合 (可能性（2）b）を私の実験上り否定 することはできない。さらに興味あることは“洗修沈

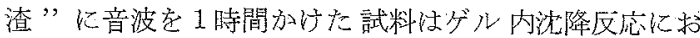
いてその沈降带の幅が広くでることで，これはウイルス 粒子の内部または表面にある抗原がウイルス粒子よりは 小さい種々の大きさの粒子となりゲル内起遠くまで搪散 するようになつたと考えると一応理解できる。

アデノウイルスの感染価の測定に際し私注予備実験の 結果加ら 28 日間という長期判定を採用した。文献的に は 6〜7日の短期間の判定を行なつている報告が多いが， 一方 Pereira ら (1959) 刑型用いて長期間の観察を行 つて晾り，3日以内では毒素の問題を考えに入れる必要 があり，9 日以上の観察を行わなければ真のウイルスの 感染価を測定できないと云つている. その他内田 (1960)， Grayston 5(1958) なども長期観察の必要性を述心てい る.アデノウイルスは感染洒の低い割に CF 価が高いと 云われているが(Hilleman ら，1955)，7日目と28日目 では感染洒に $10^{3} \sim 10^{3.75}$ の差があり， 7 日判定の場合 と比較して CF 価と感染価の比率㣖大部異つてくるので
感染拪に比して CF 価方高いということをアデノウイル スの特微の一つとするの恔当でない，むしる感染価測 定法が不適当であつたと考える心゙きであるう。

\section{総括}

1. アデノウイルス 3 型の増殖に関しては細胞におい て2 21 時間で感染価の上昇が始まり，CF 価の上昇は 30 時間より始まつた。すなわち感染価の上昇は CF 価の上 昇よりやや早かつた 液層では 46 時閒に晾ても感染 価，CF 価ともに上昇を認めなかつた。

2. アデノウイルス 3 型ウイルス液毫超遠心でウイル ス粒子と S抗原に分ち，さらに洗沙を繰り返した後のウ イルス粒子は弱いながら明らかに CF 反応性を示す ( わゆる“V抗原”ことが明らかとなつた。

3. “V抗原”と $\mathrm{S}$ 抗原を比較する実験を行なつた。 その結果，熱抵抗性において差を認めず，エーテル耐性 の点です差を䛄めず，ゲル内沈降反応に执いて両者の特 異性が同一であることが明らかとなつた。

4.ウイルス粒子中に扮讨る S抗原の存在様式につい て，音波処理によるウイルス粒子の破壊後に CF 価が上 昇したこと，抒よびゲル内沈降反応に执いて咅波処理り イルス粒子がより幅の広、沈降帯等形成したことはりイ ルスの構成成分の一部として S抗原が存在している可能 性を示していると考えられた。

乙かしS抗原がウイルス粒子表面に強固に收着されて いる可能性あるい性原がウイルス粒子とは別個に $15,000 \mathrm{rpm}$ で沈澱する大ささの粒子として存在してい るかもしれないという可能性を除外することはできなか 2た.

5. アデノウイルスの感染価の測定には28日の長期 観察を行うを従来云われていたような感染価に比して CF 価方高いと云うことはない。

\section{謝辞}

稿を終るに臨み，御留篤なる御指導及び御校閲るいた

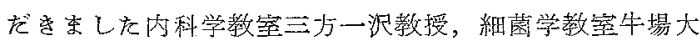
蔵教授，佐々末正五助教授，内科学教宔勝正孝講師に衰 心ょり感謝し，なた終始多大なる御援助をいただきい た細菌学教安橋本一男講師その他教䇪蕒各位飞謝意を表 ᄂ昰与。

\section{Summary}

It was the purpose of this paper to identify the complement fixing (CF) antigen from adenovirus type 3 particles, namely $\mathrm{V}$ antigen, and to compare the characteristics between $\mathrm{V}$ antigen and soluble antigen ( $S$ antigen). Some efforts have been made to describe the similarity and difference of these 
two antigens. Results were as follows:

1) In growth experiment of adenovirus type 3, infectivity titer in Hela cells began to rise in 21 hours and the increase of CF titer was noted in 30 hours, indicating that the infectivity titer preceded the CF titer. In extracellular media, however, both titers did not rise even after 48 hours.

2) Virus particle and $\mathrm{S}$ antigen were separated through ultracentrifugation from adenovirus type 3 preparation. Virus particle repeatedly washed several times evidently showed reactivity to $C F$ antibody. ("V antigen".)

3) Experiements to compare "V antigen" and $S$ antigen clarified that there was no difference in resistence to either heat or ether. Specificity of these two antigens was determined to be same by gel-diffusion method.

4) Destruction of virus particle by sonic oscillation resulted in the rise of CF titer. Virus particle treated by sonic oscillation formed a broader band in geldiffusion method. These facts might indicate that $S$ antigen was a part of virus particle constitution. But doubts still remained unsettled that $S$ antigen was possibly adsorbed in the surface of virus particle or exsist as another particle sedimentable by ultracentrifugation apart from virus particle itself.

5) Observation as long as 28 days was necessary for the determination of infectivity titer of adenovirus. Using this method for infectivity titration, it was not demonstrated that $\mathrm{CF}$ titer was high in comparison with infectivity titer in adenovirus.

\section{文献

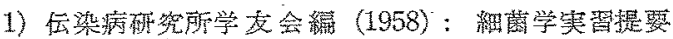
丸善㧣式会社，東京. - 2) Friedman, M. and De Berry, P. (1959) : Thermal differentiatiation of the adenovirus complement fixing antigens. J. Immunol, 82, 535-541. -3) Fukumi, H., Nishikawa, F. and Ejima, S. (1957) : The relationship between cytopathic changes and virus multiplicotion in HeLa cells infected with adenovirus. Jap. J. Med. Sci. \& Biol. 10, 321-328. - 4) Ginsberg, H. S. (1958): Characteristics of the adenovirus. III, reproductive cycle of type 1 to 4 . J. Exp. Med., 107, 133-152. -5) Grayston, J. T., Loosli, C. G., Smith, M., Mc Carthy, M. A. and Johnston, P. B. (1958) : Adeno. virus. $I$, the effect of total incubation time in HeLa cell cultures on the isolation rate. J. Inf. Dis., 103, 75-85. -6) Hilleman, M. R., Tousimis, A. J. and Werner, J. H. (1955) : Biophysical characterization of the RI (RI-67) viruses. Proe. Soc. Exp. Biol. \& Med., 89, 587-593. 一7) 鲃野礼作 (1954)：ウイル 入研究の新手技，組織培善法の応用につマて．臨床病

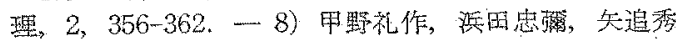

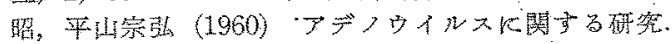

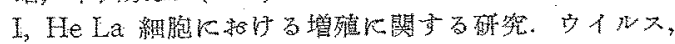
10, 267-274. - 9) Lieberman, M. and Friedman, M. : (1959) : Growth characteristics of adenovirus, $I$, production and release of complement fixing antigen and infectious virus. J. Immunol, 82, 1-8:10) Lief, F. S. and Henle, W. (1956): Studies on the soluble antigen of influenza virus. I, the release of S-antigen from elementary bodies by treatment with ether. Virology, 2, 753-771. 一-11) 野島德声, 岩俈三郎 (1957)：リフトパレ一熱りイルス感染過程 と出現する抗原について。 ウイルス，7，348-350. 一 12) Pereira, H. G. and Kelly, B. (1957): Doseresponse curves of toxic and infective actions of adenovirus in HeLa cell cultures. J. Gen. Microbiol, 17,517-524. - 13) Pereira, H. G. (1958) : A protein factor responsible for the early cytopathic effect of adenovirus. Virology, 6, 601-611. -14) Pereira, H. G. 1959a). Adenovirus. Brit. Med. Bull., 15, 225230. -15) Pereira, H. G., Allison, A. C. and Balfour, B. $(1959 \mathrm{~b})$. Multiplication of adenovirus type 5 studies by infectivity titrations and by the fluorescent antibody technique. Virology, 7, 300-314. -16) Rowe, W. P., Huebner, R. J., Hartley, J. W., Ward, T. G. and Parrot, R. H. (1955) : Studies of the adenoidal-pharyngeal-conjunctival (APC) group of viruses. Am. J. Hyg., 61, 197-218. -17) Rowe, W. P., Hartley, J. W., Roizman, B. and Levy, H. B. (1958) : Characterization of a factor found in the course of adenovirus infection of tissue cultures causing detachment of cells from glass. J. Exp. Med. 108，713-729. - 18) 鈴木鑑 (1960). グル内搪散法 (2). 二次元摭散法 (主として Ouchterlony 法)。园学 ○㕧み，35，87-92. - 19) 内四清二郎等(1960)：ア デウイルスに関するシンポジウ，綜合医学，17, 181-251. -20) Werner, G. H. (1956) : Complement fxing antibody in guinea pigs immunized with type 3 adenopharyngo-conjunctival virus. J. Bact., 72, $568-569$ 